\title{
Construcciones teatrales provisionales en La Coruña de 1900. Otra tipología de arquitectura efímera lúdica
}

\author{
LuCía M. ViLLASUSO FERnÁNDEZ1. \\ Transitory theatrical constructions in a Coruña in 1900. Another \\ typology of festive ephemeral architecture
}

\begin{abstract}
RESUMEN
Este documento muestra una serie de construcciones teatrales temporales que se levantaron en A Coruña alrededor de 1900, esclareciendo además los eventos que las propiciaron, las ubicaciones más usuales así como otros aspectos relativos al estilo, material, tamaño o color de las mismas.

PALABRAS CLAVE: teatro, efímero, arquitectura, tipología, lúdico, Eclecticismo, Modernismo, Coruña, 1900.

ABSTRACT

The following document presents the provisional theater constructions that raised in A Coruña by 1900, clarifying, moreover, the events that generated them, the most usual locations and other aspects related to their style, material, size or colour.

\section{KEYWORDS}

theater, ephemeral, architecture, typology, festive, Eclecticism, Art Nouveau, Coruña, 1900.
\end{abstract}

La arquitectura lúdica está relacionada con la arquitectura conmemorativa y con la arquitectura comercial ${ }^{2}$, porque tanto en la arquitectura conmemorativa como en la lúdica hay mucho de festivo, aunque la mayor parte de las obras arquitectónicas conmemorativas son generadas por un hecho externo que todos los vecinos pagan indirectamente a través de los impuestos recaudados por el ente municipal, que además suele ser el promotor principal; mientras que en la arquitectura lúdica un hecho local cíclico atrae a promotores privados que vienen expresamente a la ciudad para instalar construcciones itinerantes en las que se ofrece un servicio - y no producto como en la arquitectura comercial — que cada usuario decide si paga, por lo que no es obligatorio su subvención ni su disfrute.

1 Doctora en Historia del Arte. Contacto: Imvf@ole.com

2 VILLASUSO FERNÁNDEZ, L. M., Arquitectura efímera de carácter conmemorativo, lúdico y comercial levantada durante la época contemporánea en la ciudad de A Coruña (Tesis doctoral s. p.), UNED, 2010. 
Con respecto a la arquitectura lúdica y comercial, ambas se levantan generalmente para eventos cíclicos y en lugares acotados, así que la diferencia radica en que la arquitectura lúdica acoge un servicio de diversión que el cliente sólo disfruta si paga y accede a su interior, mientras que en la arquitectura comercial el cliente se sitúa en las inmediaciones de la construcción y paga por un producto.

Centrándose en la arquitectura teatral, el teatro durante la llustración fue considerado un edificio destinado al bien común y a la instrucción general, por lo que surgieron numerosos tratadistas que abordaron temas sobre la acústica, la óptica, la forma y las dimensiones de la sala del teatro, que se materializaron en un edificio teatral compacto, de estilo clásico e inspiración grecorromana, con un pórtico columnado en la fachada de acceso y situado exento en las principales calles o plazas, convirtiéndose así en un elemento dinamizador de la vida local.

Posteriormente y entrando ya en el siglo XX el teatro pasó de ser un vehículo de cultura a ser un lugar de divertimento, apareciendo los teatro-cines, los salones de variedades y otros experimentos teatrales caracterizados por el aumento de aforo y superficie - generalmente de planta rectangular-, por la pérdida de palcos, por tener un estilo y decoración interna basado en las directrices marcadas por el promotor - más preocupado por el aspecto económico que artístico-y por acoger espectáculos más populares como el cuplé, el flamenco o la opereta, provocando que en ocasiones fueran acusados de ser una perversión del gusto.

Una vez expuestos los aspectos más relevantes del teatro como edificio se pasa a analizar el caso coruñés, que es el objetivo del presente artículo y para ello se parte del dicho popular «Vigo trabaja, Santiago reza y A Coruña se divierte» del que se deduce el carácter alegre y sociable de los coruñeses, sobre todo en verano y especialmente en agosto, cuando se celebraban la mayor parte de fiestas patronales y romerías, para las que se levantaban, además de plazas de toros, cines o circos, teatros que se caracterizaron principalmente por presentar una escasa innovación estructural debido a la severa legislación sobre seguridad en los espectáculos públicos, por proliferar alrededor de 1900 en la concurrida zona del puerto y los jardines de Méndez Núñez, por estar realizadas generalmente en madera, por tener una distribución sencilla que constaba principalmente de vestíbulo, patio de butacas, escenario y zona de maquinaria y por presentar una fachada en estilo hispanomusulmán o modernista que invitaba a entrar en un mundo de fantasía, evasión, alegría y divertimento.

Antes de existir un edificio teatral ex profeso y permanente en A Coruña las compañías representaban en tablados rudimentarios levantados sobre postes hincados en la tierra y con cortinajes de fondo, después en espacios ambulantes y en edificios teatrales semipermanentes ${ }^{3}$.

${ }^{3}$ En el siglo XVII era frecuente que compañías que venían a Santiago para la festividad del apóstol Santiago o del Corpus fuesen contratadas por el consistorio herculino para dar representaciones el día del Rosario. 
Posteriormente y además de los teatros que no se adaptaron a las nuevas necesidades y sobre todo, de los que no superaron el paso del tiempo, es decir, de aquellos que sólo fueron efímeros en función o forma, como el «Coliseo Viejo» (1823-1889) o el «Coliseo de San Jorge»-«Teatro Principal» (1838-1867), en A Coruña existieron varios ejemplos de arquitecturas teatrales de vocación efímera que son los que a continuación se estudian de manera diacrónica.

Tras el incendio del «Teatro de Variedades» ${ }^{4}$ en 1804 , el denominado «Teatro Provisional» se levantó rápidamente en la actual zona de Puerta Real —donde antes estuviera el teatro efímero de Nicola Settaro ${ }^{5}$ - y aunque en principio iba a ser

En 1617 por ejemplo, Fernando de Mourelos, mayordomo de las fiestas del Rosario de A Coruña contrató por seiscientos reales, comida, cama y posada «una compañía de funámbulos que Lorito Brechola, italiano, tenía en Santiago a la sazón (...) son tres volteadores, dos hombres y una mujer, y dos músicos y un arlequín, a hacer la fiesta de Nuestra Señora del Rosario que se hace a primero, segundo y tercer día del mes de julio. Han de ir en procesión con sus trompetas y violones y en el tablado hacer una danza de toqueado, y en la plaza o lugar señalado han de poner las maromas y voltear en ellas y poner el caballo de madera y hacer todo entretenimiento que supieren hacer en los tres días».

En 1624 el mercader coruñés Andrés Santos contrató al autor de comedias Lorenzo de los Ríos «para hacer dos comedias, de las mejores que tuviere, en las fiestas de Ntra. Sra. del Rosario de dicha ciudad los días primero y dos de julio. El Andrés Santos, mayordomo de las fiestas, haría a su costa los tablados necesarios y satisfaría a Lorenzo de los Ríos, mil reales por las dos representaciones». PÉREZ COSTANTI, P., Notas Viejas Galicianas, t. II., Vigo, Sindicatos Católicos, 1925, pp. 26 y 30-1.

Para la venida de Mariana de Neoburgo, el Comercio de la ciudad celebró el segundo día una mascarada en la plaza frente al Palacio, en la que se habían dispuesto varios tablados y en la que intervinieron cincuenta caballeros de ilustre linaje lujosamente ataviados. MARTÍNEZ-BARBEITO, I., «Una reina en La Coruña» en diario La Voz de Galicia, 1/9/1965; TETTAMANCY GASTÓN, F., Apuntes para la historia comercial de La Coruña, p. 221 y VEDIA Y GOOSSENS, E., Historia y descripción de La Coruña, La Coruña, 1845, p. 197.

${ }^{4}$ En 1771 se construyó en la actual plaza del Humor — con cierta rapidez y pobres materiales— el teatro denominado «Teatro de Variedades» o «Coliseo» el cual tenía una capacidad para 300 personas, era de madera y planta rectangular, estaba formado por dos pisos de palcos decorados — divididos por mamparas de madera- y un gallinero cerrado con balaustres, además del patio, donde se disponían sillas de brazo. En 1772 fue adquirido por el Ayuntamiento para restaurarlo, quien lo cerró de 1779 hasta 1791 por motivos de seguridad por lo que las compañías teatrales que visitaron la ciudad en esos años actuaron en las plazas y calles principales o en recintos particulares, como el almacén de los herederos de don Jerónimo Hijosa, que de 1789 a 1791 funcionó como teatro. Desde 1796 se solicitaron nuevas reformas para el «Teatro de Variedades» pero no se realizaron porque en 1804 el local sufrió un incendio. SÁNCHEZ GARCÍA, J. A., La Arquitectura teatral en Galicia, A Coruña, Fundación Pedro Barrié de la Maza, 1997, pp. 48-9 y 99; SORALUCE BLOND, J. R., «El espacio del espectáculo: Los primeros teatros de Galicia» en Boletín Académico da Escola Técnica Superior de Arquitectura da Coruña, no 9, La Coruña, Universidade da Coruña, 1988, p. 34; VIGO TRASANCOS, A., La arquitectura de la Ilustración, La Coruña, Vía Láctea Editorial, 1995, p. 144; BARREIRO FERNÁNDEZ, X. R., Historia de la ciudad de La Coruña, La Coruña, La Voz de Galicia, 1986, pp. 303-5 y GONZÁLEZ CATOYRA, Temas coruñeses, La Coruña, Ayuntamiento de La Coruña, 1991, pp. 343 y 434.

${ }^{5}$ El primer expediente sobre la realización en esta ciudad de un teatro efímero data de 1768 cuando Nicola Settaro solicitó construir uno en la actual zona de Puerta Real. Este teatro estuvo en pie hasta 1769 , costó 170.000 reales, era portátil, de madera y su diseño posiblemente similar al que levantara en Santiago, el cual era exento, cubierto, de madera, posiblemente rectangular y de dos pisos, con un tablado con bastidores laterales y zona para músicos, cazuela, palcos y bancos, tal y como lo había diseñado el arquitecto Domingo Lois de Monteagudo, siendo el carpintero Francisco Casal. SÁNCHEZ GARCÍA, J. A., Op. cit., pp. 43-5; VIGO TRASANCOS, A., Op. cit., p. 143 y VEDIA Y GOOSSENS, E., Op. cit., p. 270. 
transitorio, soportó numerosas reformas y reparaciones ${ }^{6}$ que le permitieron ser multifuncional ${ }^{7}$ hasta que sucumbió en 1823 . Este edificio teatral promovido por Bartolomé Alegre -poco interesado en los aspectos formales- era sencillo, exento, cubierto, de madera y en él trabajó el maestro de obras José Carballo y el arquitecto Fernando Domínguez Romay, por lo que se supone que su interior sería similar al del teatro que proyectara dicho arquitecto en 1790 para sustituir al «Teatro de Variedades ${ }^{8}$, es decir, con una sala elíptica y un aforo de 800 personas distribuidas entre aproximadamente 40 palcos dispuestos en 3 alturas, bancos con y sin respaldo y lunetas pintadas en la platea, además del espacio para los espectadores de pie $^{9}$.

A partir del último cuarto del siglo XIX las arquitecturas teatrales proliferaron principalmente en los jardines de Méndez Núñez y durante las fiestas de Mª Pita, de manera que en 1880 se dio permiso a Antonio Aller para situar provisionalmente durante las fiestas veraniegas y detrás del palco de música del paseo de Méndez Núñez un «palacio físico mecánico» de $15 \times 5$ m (figs. 1 y 2) ${ }^{10}$.

Por los bocetos de los alzados presentados se deduce que poseía una cubierta a dos aguas, acceso frontal y estaba muy adornado — sobre todo en la fachadacon banderolas, grecas, otros elementos geométricos y una cartela conmemorativa que decía «A la gloria de María Pita» en los diferentes frisos escalonados, desconociéndose sin embargo su autor y altura.

En verano de 1884 Nicandro Fariña solicitó construir en un espacio de $30 \mathrm{~m}^{2}$ del paseo de Méndez Núñez y con carácter exclusivo y «provisional» ${ }^{11}$, un edificio de hierro con destino a teatro-circo, indicando que le daría animación, movimiento y belleza al paraje.

Los accionistas del Teatro Principal protestaron, pero igualmente se le concedió el permiso a cambio de ceder el edificio al Ayuntamiento al finalizar la concesión, dar espectáculos en favor de la beneficencia y pagar 1'5 ptas./m² al año,

\footnotetext{
6 Durante la guerra de la Independencia todos los teatros gallegos sufrieron daños y casi todos desaparecieron, salvo este teatro que fue restaurado por orden del mariscal Soult y que soportó más reparaciones —sobre todo alrededor de 1820— hasta su derribo. SÁNCHEZ GARCÍA, J. A., Op. cit., p. 101.

7 Fue lugar de celebración de la proclamación de la Constitución de Cádiz en 1812 y de la proclamación del rey Fernando VII en 1815, también se celebraron en él asambleas, tertulias patrióticas y diferentes actividades propagandísticas políticas. SÁNCHEZ GARCÍA, J. A., Op. cit., pp. 102-3.

${ }^{8}$ En 1766 el Ayuntamiento solicitó al ingeniero Feliciano Míguez un proyecto para construir un teatro permanente pero no se llevó a cabo, tampoco se materializó el proyecto presentado por el arquitecto Ventura Rodríguez en 1768 ni el que Fernando Domínguez Romay proyectó en 1790. SÁNCHEZ GARCÍA, J. A., Op. cit., pp. 68-71.

9 Archivo Municipal de A Coruña (AMC), Sección de Teatro, caja (1768-1809); SÁNCHEZ GARCÍA, J. A., Op. cit., pp. 99-103 y VIGO TRASANCOS, A., Op. cit., p. 145.

10 AMC, Vía pública, caja 2153.

11 Por un plazo de 50 años. Ibídem.
} 
por lo que este teatro-circo resultó ser el primer ejemplo de esta tipología híbrida en la ciudad ${ }^{12}$.

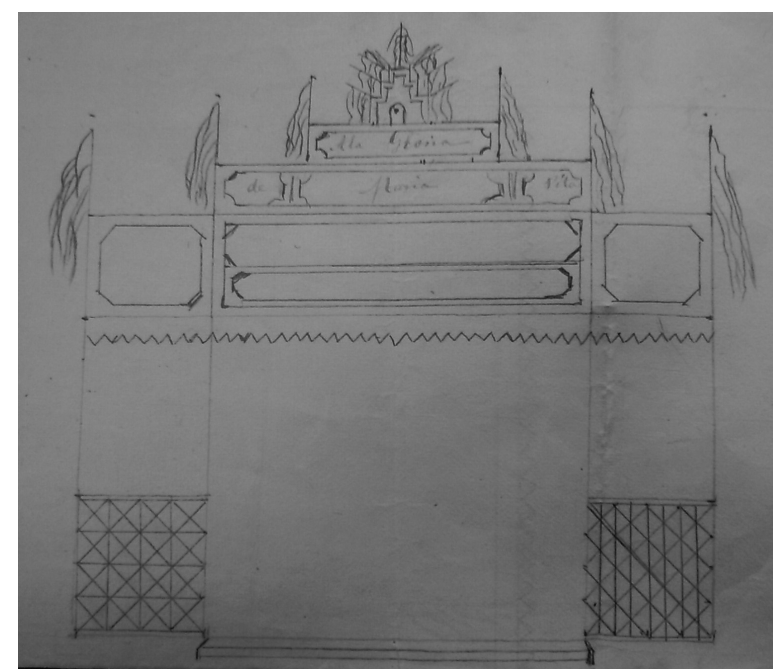

Fig. 1. Teatro de A. Aller: fachada, 1880.

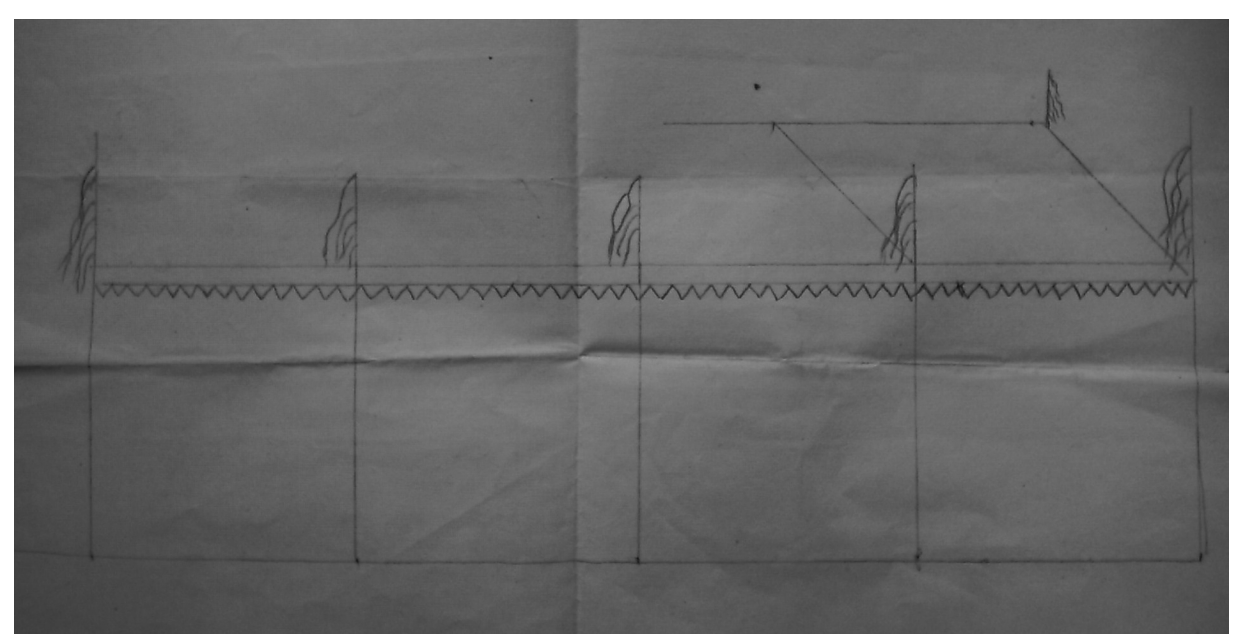

Fig. 2. Teatro de A. Aller: alzado lateral, 1880.

También se concedió licencia a Benito Sánchez para instalar provisionalmente durante los meses de verano y en el paseo de Méndez Núñez, un cómodo pabellón de madera pintada (fig. 3), de buen gusto y ornato, con destino a teatro

12 Ibídem. 
mecánico para disfrute de los niños, «donde estuvo en 1883 el teatro de la risa «La Rigolade » ${ }^{13}$, de $24 \mathrm{~m}$ de largo por 6 de ancho $\left(144 \mathrm{~m}^{2}\right)$, de nueva construcción, de madera de pino de Holanda cepillada y machihembrada con cubierta de lo mismo superpuesta, todo exteriormente pintado con la correspondiente fachada, conforme al adjunto plano que acompaña, con objeto de darse en el mismo funciones de muñecos o sea un teatro guiñol»14.

Del dibujo se desprende que medía $3 \mathrm{~m}$ de altura -4 en su cota máxima-, tenía cubierta a dos aguas, era de planta rectangular, tenía un vestíbulo diferenciado y una puerta a través de la que se accedía al sencillo interior tripartito dividido en gallinero a los pies, platea en el medio — con dos puertas a mayores-y escenario en el otro extremo; contraponiéndose a esta estructura interna tan sencilla, la exuberante y vistosa decoración exterior, destacando los motivos literarios y vegetales del frontón de la fachada.

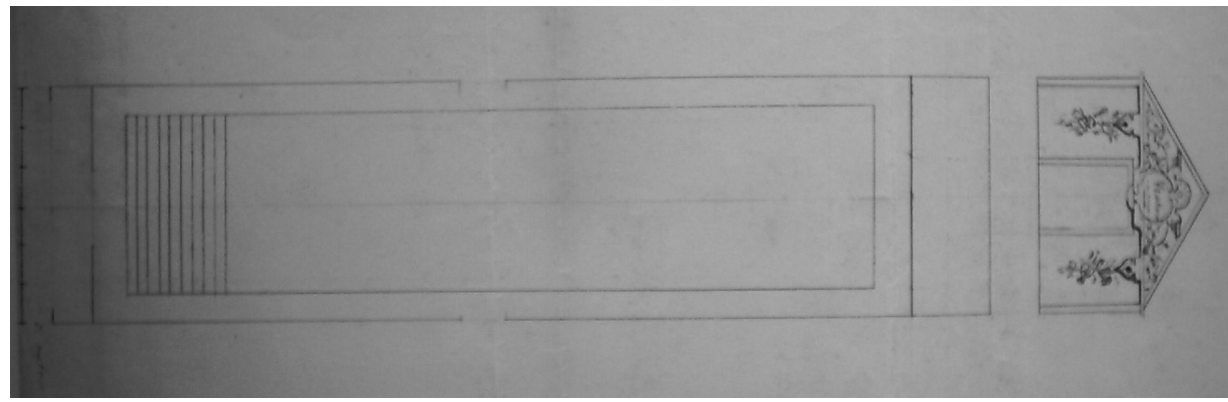

Fig. 3. Teatro de B. Sánchez: fachada y planta, 1884.

En la primavera de 1885 se instaló un teatro ambulante de 20x6 m en el paseo de Méndez Núñez —aproximadamente donde estuviera el anterior-que ofrecía un espectáculo titulado «Los espectros vivos» ${ }^{15}$.

El circo provisional que había construido Mr. Carlos Ferroni Ginarta en la zona del Corralón a finales de 1884 se convirtió a mediados de 1885 — siendo ya propietario Juan Solís Carballeda- en teatro-circo al añadírsele un pequeño escenario en el lugar que ocuparan las caballerizas ${ }^{16}$.

13 «La Rigolade» era un pabellón propiedad de Eduardo Gimeno que funcionó como «teatro de la risa» durante 1883-5 y en el que se exhibía al público una galería de figuras de cera y espejos de transformación. Ibídem.

14 Ibídem.

15 AMC, Vía pública, caja 2154.

16 La modificación del circo fue aprobada por el gobernador civil de la provincia y cuando el arquitecto Juan de Ciórraga lo reconoció afirmó: «Transforman en teatro circo con la colocación de un pequeño escenario en el lugar que ocupaban las caballerías, hallo que, atendiendo a su carácter provisional reúne al presente las condiciones restantes de solidez para los usos a que se intenta destinar». AMC, Vía pública, caja 2153. 
A Santiago Delgado le dieron a continuación licencia durante 3 meses para establecer un teatro mecánico portátil en la zona sur del paseo de Méndez Núñez, de $19 \times 7 \mathrm{~m}\left(133 \mathrm{~m}^{2}\right)$, de hierro y madera, para lo cual presentó un proyecto en acuarela (fig. 4) en el que se apreciaban —igual que en el teatro de B. Sánchez- reminiscencias de las acroteras, columnas y frontones de los templos griegos, posiblemente para dignificar la construcción y el espectáculo y obtener así con mayor facilidad la licencia, porque está comprobado que cuanto más digna era la construcción en cuanto a forma y función, más posibilidades había de conseguir el permiso.

También se aprecia en el boceto que la fachada era de color rosa, estaba decorada con banderines y tenía — de nuevo, como en el teatro de B. Sánchez- una disposición tripartita con acceso en el centro ${ }^{17}$.

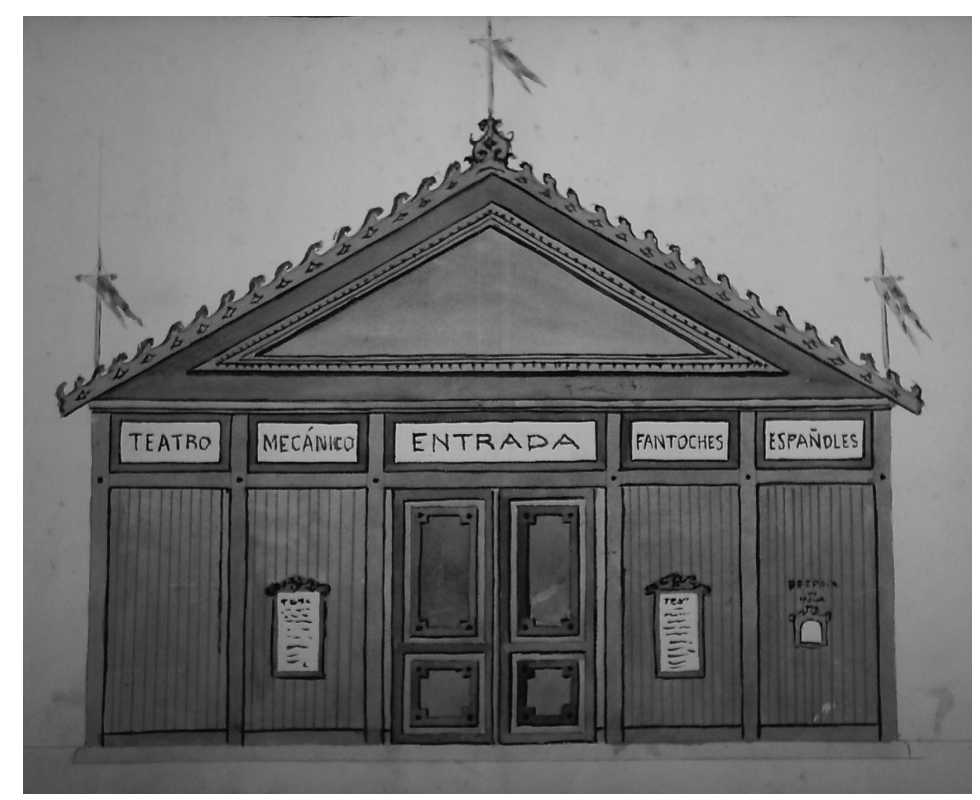

Fig. 4. Teatro de S. Delgado, 1885.

En verano de 1886 Álvaro Tudela instaló provisionalmente en el salón sur del paseo de Méndez Núñez, para recreo y aliciente a los concurrentes a las fiestas de María Pita, un teatro mecánico (fig. 5) de madera machihembrada, acepillada y bien pintada, de $27 \times 8 \mathrm{~m}\left(216 \mathrm{~m}^{2}\right)$ y de bellas, vistosas y armónicas formas.

Era un teatro muy similar en estructura, forma y decoración al que S. Delgado levantara en 1885, pero más complejo, pues aunque su fachada — esta vez en to-

17 AMC, Vía pública, caja 2154. 
nos verdes - también era tripartita, ésta estaba limitada en los extremos por la «contaduría» y por el «despacho» mientras que en el medio se encontraba una antesala — limitada en su frente por una balaustrada — desde la que se accedía al interior del recinto, anticipándose así a la estructura del célebre Pabellón Lino.

En 1887 quiso mejorarlo y ampliarlo ${ }^{18}$ con el fin de convertirlo en permanente hasta el punto de proponer que se rigiese por la Junta Provincial de Teatros pero la Comisión concluyó que la nueva obra no se había construido de igual modo que el resto de la instalación «por cuanto en su parte central lleva la cubierta un cuerpo de mayor altura, que siendo indispensable para el establecimiento de la maquinaria y decoraciones del escenario, no se halla sin embargo especificado en la solicitud (...). Que la prolongación dada al pabellón es de $14 \mathrm{~m}$, o sea dos más que los solicitados y concebidos, resultando un exceso superficial de $16 \mathrm{~m}^{2}{ }^{19}$.

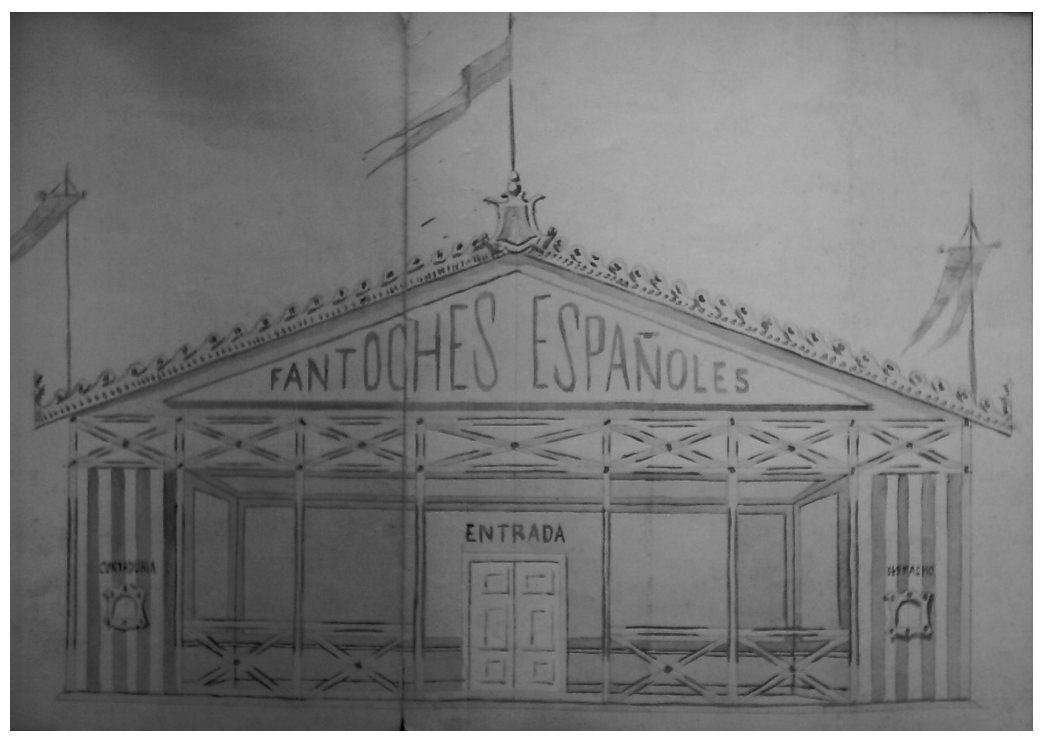

Fig. 5. Teatro de A. Tudela, 1886.

Por otra parte, a finales de 1887 los concejales solicitaron la desaparición de todas las instalaciones del salón sur del paseo de Méndez Núñez porque interrumpían el esparcimiento y estropeaban los árboles, así que se acordó retirar todas las instalaciones del paseo de Méndez Núñez antes de 15 días —entre la que se encontraba la de A. Tudela-y no dar más concesiones porque para esta fina-

18 «Dueño del barracón de fantoches establecido en uno de los paseos laterales (...) deseando ampliar dicho barracón y sin salirse de las comisiones del plano (...) y no variándose en nada la forma externa del mismo». Ibídem.

19 Ibídem. 
lidad estaba la zona de la Junta de Obras del Puerto, en la calle la Marina, donde ya había quioscos ${ }^{20}$.

Con el fin de proporcionar en los meses de verano distracciones a los forasteros, José María Rodríguez solicitó en 1890 licencia para levantar de manera provisional y en la zona sur del paseo de Méndez Núñez, un teatro de madera machihembrada, cepillada y bien pintada.

Presentó el mismo proyecto de teatro que presentara en $1887^{21}$ pero se le denegó por falta de espacio dado que habían crecido los árboles y no cabría el teatro, así que el arquitecto Domingo Rodríguez Jimeno redujo las dimensiones del diseño anterior, quedando en $40 \times 8 \mathrm{~m}$ y casi $6 \mathrm{~m}$ de alto (figs. 6-9).

Fue uno de los teatros efímeros coruñeses más elaborado y presentaba —como los teatros permanentes - una fachada de clara influencia griega con decoraciones de elementos musicales en el tímpano y un interior bien definido, con vestíbulo diferenciado, gallinero, sala con lunetas, bancos y palcos, zona para la orquesta, escenario y almacenes ${ }^{22}$.

${ }^{20}$ Así que la solicitud de Sebastián Bardaji de 1889 para colocar en el paso de Méndez Núñez una caseta de madera y lona, para la que pidió un terreno de 16x8 $\mathrm{m}$ con el fin de exponer al público un espectáculo durante las fiestas de María Pita, se denegó por el acuerdo tomado por la Comisión. Ibídem.

En 1896 se denegó a Antonio de la Rosa —director del teatro mecánico ambulante titulado «Los espectros»- el sitio de $25 \times 7 \mathrm{~m}$ que había solicitado para las fiestas de María Pita debido al acuerdo de 1887. Ibídem.

Por el mismo acuerdo se denegó en 1897 a Andrés Dordan colocar durante casi un mes un pabellón en el paseo de Méndez Núñez para instalar un teatro mecánico y dar espectáculos de fantoches y metempsicosis, de 10x9 m. Ibídem.

En 1902 Dominga Espida y Rafaela Longo solicitaron permiso para instalar en el paseo de Méndez Núñez un barracón de 5x5 m para exhibir «La reina de los mares» pero la Comisión lo denegó porque no había terreno adecuado para ello. AMC, Vía pública, caja 2155.

En 1911 Enrique Vidal Quintela solicitó permiso para instalar provisionalmente en la parte posterior del pabellón «La Perla» del paseo de Méndez Núñez un pabellón elegante e higiénico destinado a cinematógrafo y espectáculos de varietés, de 8x25 o $30 \mathrm{~m}$. Era un pabellón que constaba de planta baja y una grada, «el salón de preferencia será elegante, bien pintado y profusamente iluminado con luz eléctrica. La galería será lo más cómoda posible, según lo permita local, y tendrá entrada independiente de la de preferente. El escenario, [será] apropósito para los espectáculos que puedan darse. [La] Sala de espera, estará bien iluminada con focos eléctricos y decorada decentemente. El pabellón será de madera y bien pintado. Puertas de salida tendrá 8. En el decorado, limpieza e higiene de pabellón, se procurará superar a cuantos de la misma índole se han instalado en el referido paseo». Se denegó porque era muy grande pero se le propuso reducir el tamaño o instalarlo en otra zona y no recurrió. AMC, Vía pública, caja 2156.

${ }^{21}$ En 1887 le concedieran licencia durante tres años para construir provisionalmente un teatro cuya superficie total era de $653 \mathrm{~m}^{2}$ (la superficie del edificio era de $490 \mathrm{~m}^{2}$, la del jardín $156 \mathrm{~m}^{2}$ y la escalinata, de $7 \mathrm{~m}^{2}$ ) pero no hizo uso de la misma. AMC, Vía pública, caja 2154.

22 Ibídem. 


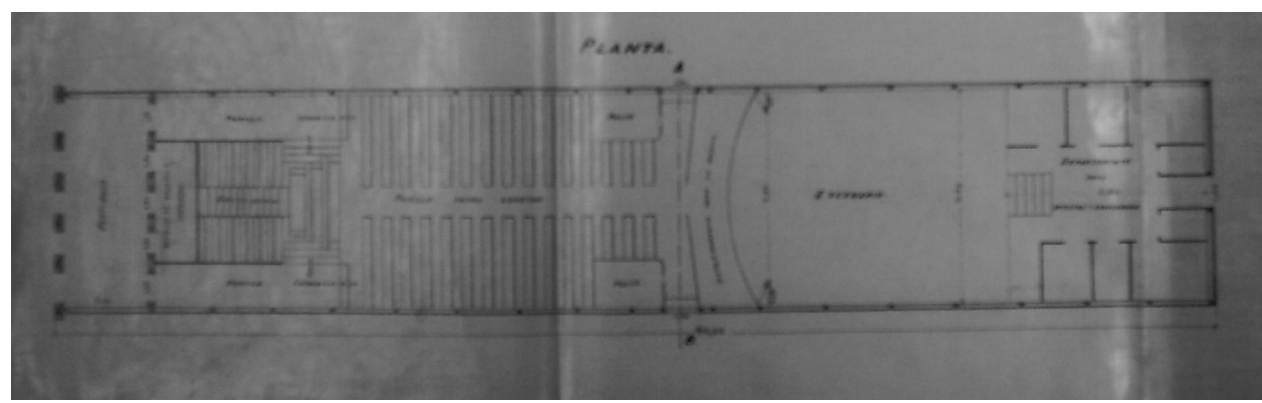

Fig. 6. Teatro de J. Mª Rodríguez: planta, 1890.

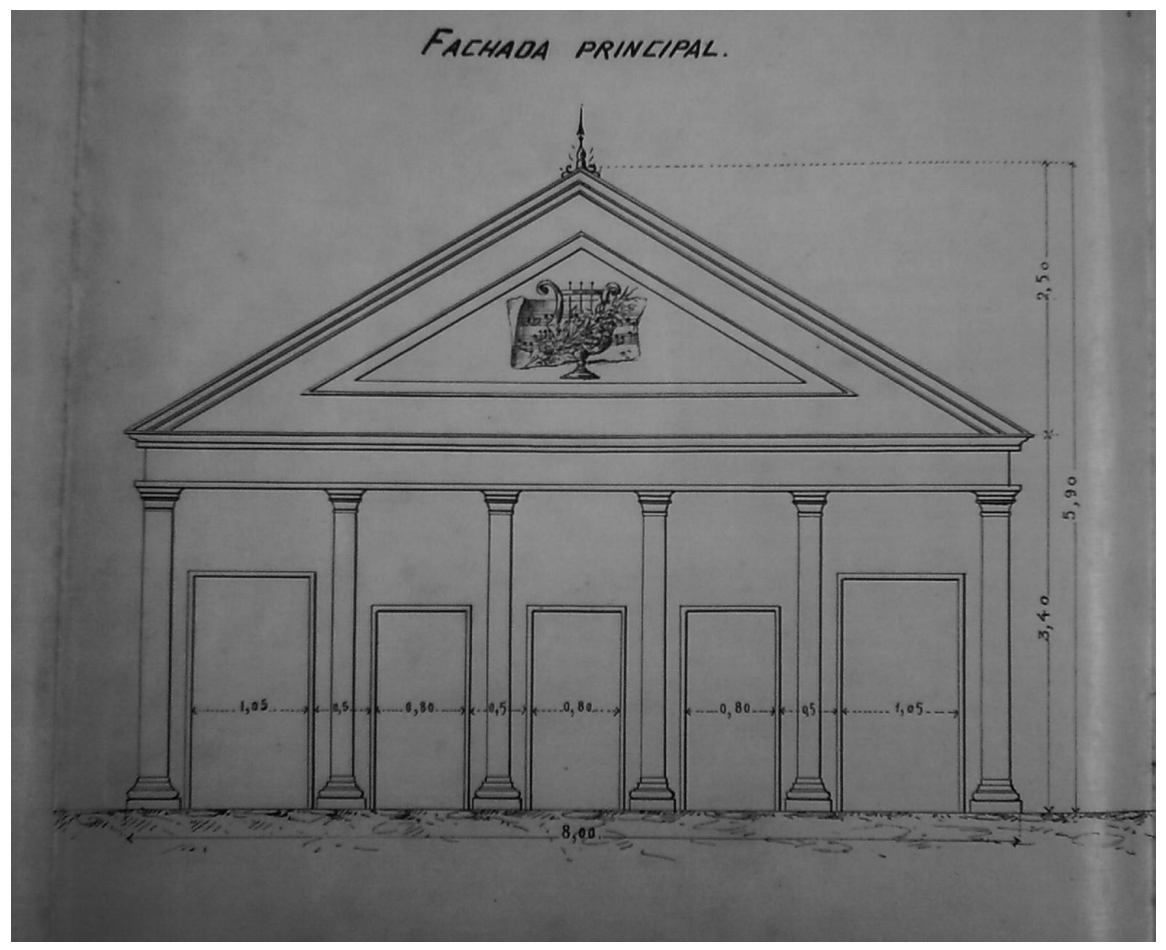

Fig. 7. Teatro de J. Mª Rodríguez: fachada, 1890. 
Construcciones teatrales provisionales en La Coruña de 1900. Otra tipología...

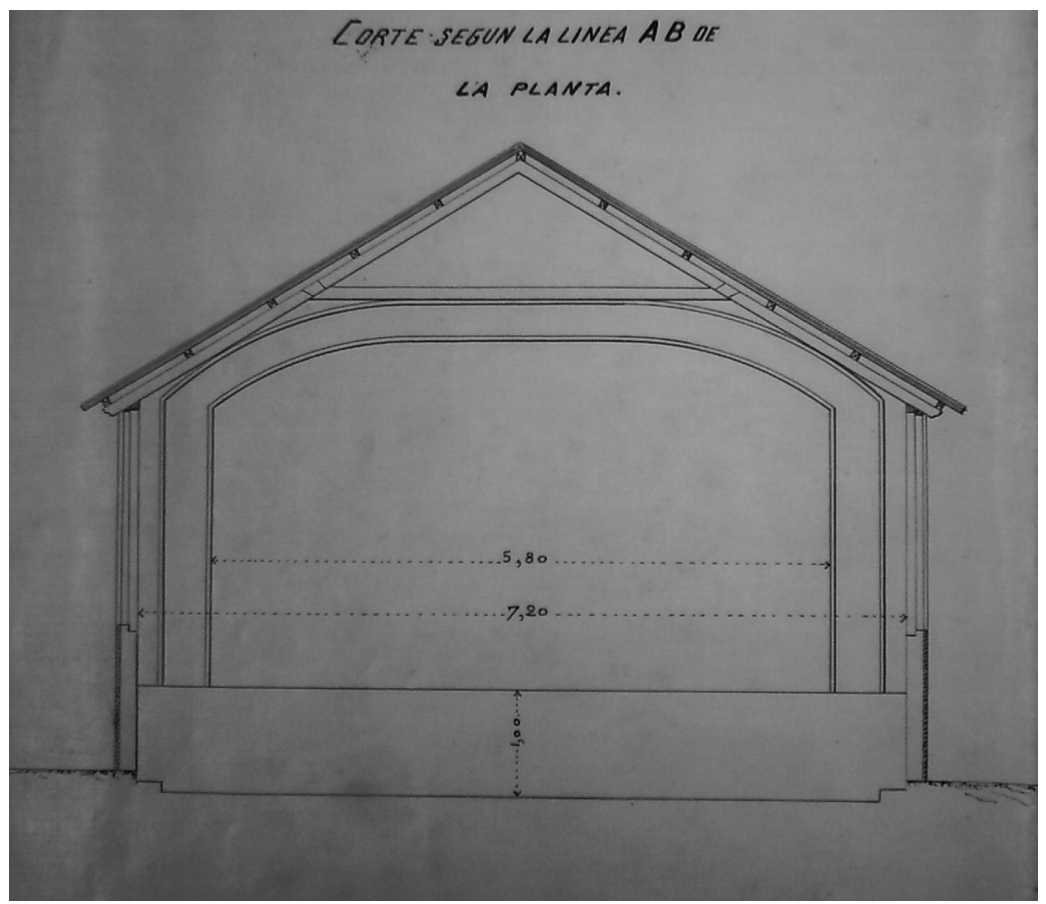

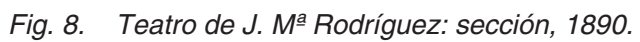

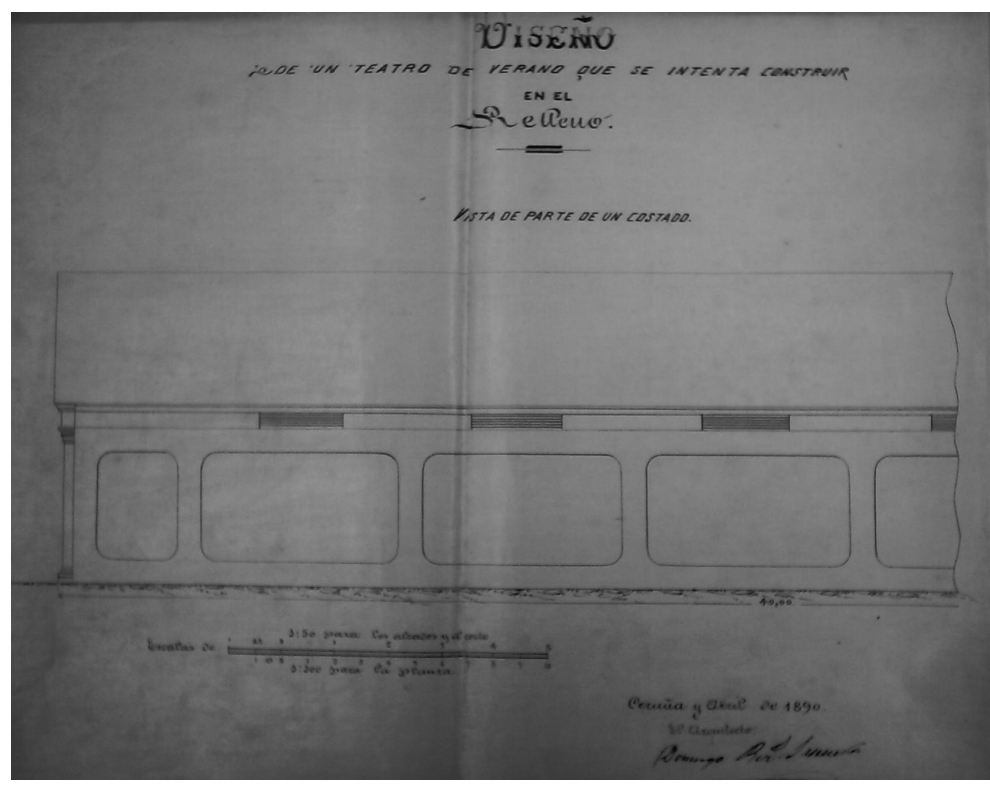

Fig. 9. Teatro de J. Maㅡ Rodríguez: alzado lateral, 1890 
En 1900 Enrique Rabadán Terrón consiguió permiso para instalar de manera provisional un pabellón de madera destinado a teatro infantil —autómatas mecánicos y fantoches, cinematógrafos y demás similares- en el paseo de Méndez Núñez, y aunque era un permiso contrario a la ley de 1887, se le concedió de manera excepcional para hacer más ameno y agradable la estancia de los forasteros en verano, dado que en ese momento no había teatro-circo ${ }^{23}$; dicha construcción medía 21'3×6'7 m (142'71 m²), estaba decorada de un modo elegante y vistoso, y era de madera cepillada, machihembrada y pintada, incluso la gradería interior.

Un año más tarde solicitó y obtuvo nuevamente - a pesar de diversas protestas ${ }^{24}$ - la autorización para instalarlo ${ }^{25}$. No hay más documentación de ambos teatros, pero sí se encontró el boceto que el mismo propietario presentó al año siguiente, en 1902, para solicitar el permiso — que fue denegado ${ }^{26}$ — con el fin de construir otro teatro, presuponiéndose sería parecido a los dos anteriores porque la mayoría de promotores que periódicamente solicitaban licencias presentaban el mismo diseño año tras año, como hizo por ejemplo J. Ma Rodríguez en 1887 y 1890.

Como se aprecia en las imágenes (figs. 10 y 11), el diseño de 1902 constaba de alzado, sección y perfil, pero no de la planta, por lo que la información que se extrae es sólo del exterior. Era ésta una construcción rectangular, de 30x9 m y casi $7 \mathrm{~m}$ de alto, es decir, más grande que en 1900, destacando la decoración de la fachada - también dividida en tres calles- en la que se apreciaban tres vanos en forma de arco de herradura con dovelas bicolores enmarcados en alfices con motivos geométricos y separados por pilastras, además de otros adornos como elementos cúficos, arquillos — ciegos o no- y delicada crestería en la parte superior, también presentes en el arco de triunfo para Alfonso XII levantado también

${ }^{23}$ AMC, Vía pública, caja 2155.

24 «El Ayuntamiento concedió autorización para levantar en el paseo de Méndez Núñez un barracón con el pomposo nombre de "Teatro de Variedades", y los vecinos de las casas que dan a la Marina protestaron ante el gobernador, del acuerdo del Ayuntamiento que entorpece el único paseo bueno que aquí tenemos. Revista gallega 3/V/1901». CASTRO DE PAZ, J.L. y FOLGAR DE LA CALLE, J.Mª., José Sellier; La Coruña y los orígenes del cine en España, A Coruña, Vía Láctea, 1996, p. 58.

Debido a la protesta de los vecinos, al final le designan el lugar donde había estado el vivero de plantas. AMC, Libros de actas, caja 130, Libro de actas 18/5/1901, p. 140.

Por los escasos ingresos obtenidos, E. Rabadán solicitó posteriormente poder dar también espectáculos de verso y zarzuela chica — si no lo ofrecía el «Teatro Principal»- y se le consintió porque el Ayuntamiento consideraba que no perjudicaba al «Teatro Principal» ya que el barracón de E. Rabadán era de menor calidad que un teatro permanente y que allí los directores de teatro no presentarían ni estrenarían obras de prestigio, aún así, protestó Lino Pérez, el arrendatario del «Teatro Principal». AMC, Libros de actas, caja 130, Libro de actas 29/5/1901, pp. 154-5.

25 AMC, Libros de actas, caja 130, Libro de actas 1/5/1901, pp. 124-6.

26 Dos meses después de instalar un cinematógrafo solicitó permiso para establecer «en el sitio que en los años anteriores ocupó un lujoso y elegante teatrillo destinado a representación de fantoches, cinematógrafos y similares, como ya en los anteriores años lo tuvo", un teatrillo destinado a dar espectáculos de la elegancia que esta población se merece, principalmente de fantoches y cinematógrafo, aunque se le denegó para evitar daños en los árboles, suelo etc. AMC, Vía pública, caja 2155. 
en la ciudad en $1881^{27}$ o en el boceto de teatro que Eugenio Alonso ${ }^{28}$ presentó en 1904, porque durante el cambio de siglo muchos artistas herculinos se basaron en el estilo hispanomusulmán de la mezquita de Córdoba — tan aclamada en ese momento- para decorar sus obras.

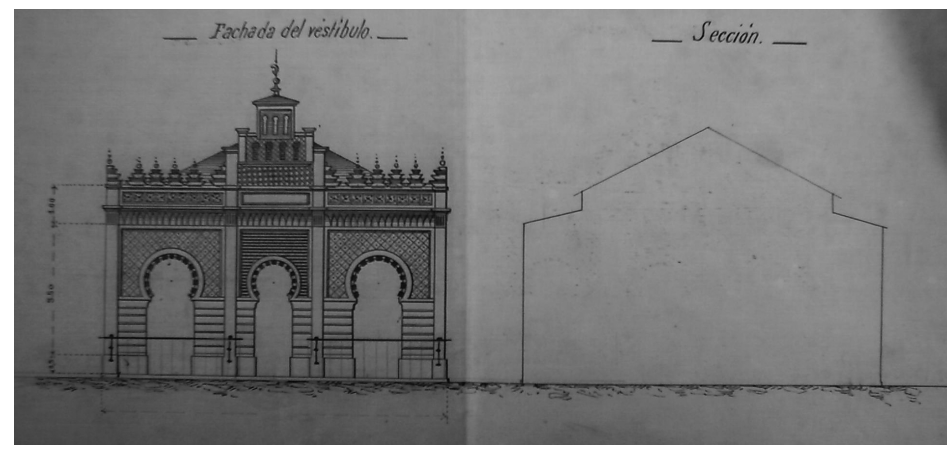

Fig. 10. Teatro de E. Rabadán: fachada y sección, 1902.

Además de un carrusel y un pabellón para venta de flores y venta y rifa de pájaros, Juan Beltrán Muiños instaló en 1902 un multifuncional pabellón —del que no se conserva el plano- para la exhibición de guiñoles, esteoramas (sic) y estereoscopios, ocupando una superficie total de casi $50 \mathrm{~m}^{2}$ en el parque de Méndez Núñez ${ }^{29}$.

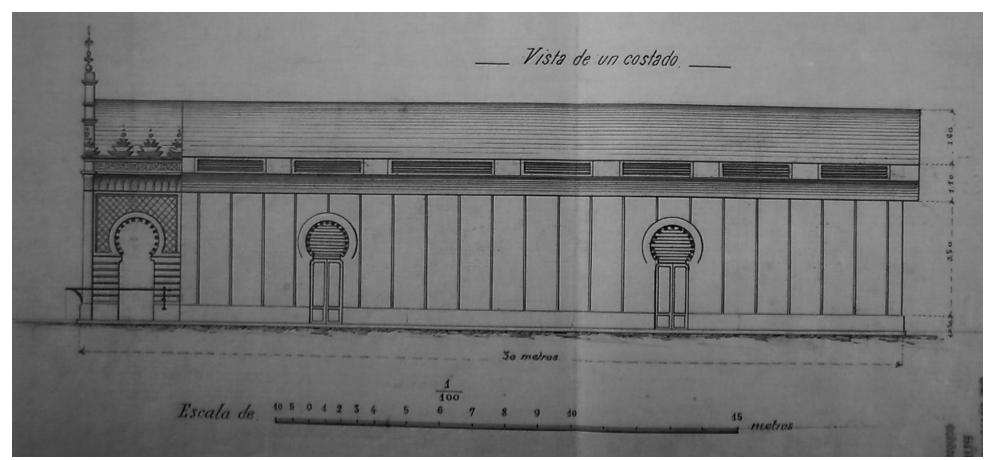

Fig. 11. Teatro de E. Rabadán: alzado lateral, 1902.

27 VILLASUSO FERNÁNDEZ, L. M., Arcos de triunfo efímeros erigidos en la ciudad de A Coruña para los monarcas que la visitaron en la segunda mitad del siglo XIX, Madrid, UNED, 2008, p. 280.

${ }^{28}$ Este último pabellón para exhibición de fantoches denominado «Teatro guiñol» medía $35 \times 10 \mathrm{~m}$, también presentaba accesos en forma de arcos de herradura con dovelas bicolores, una fachada más decorada que el resto de muros, con tres calles separadas por arcos sobre columnillas y abundante decoración geométrica, arquillos ciegos y banderas en la parte superior; mientras que en planta el espacio estaba dividido en vestíbulo, sala - a su vez dividido en general y preferente- y en escenario, con zona para orquesta y guardarropa, pero no se creó por falta de espacio en el paseo de Méndez Núñez. AMC, Vía pública, caja 2155.

${ }^{29}$ Ibídem. 
Debido al éxito obtenido desde 1898 exhibiendo películas en el «Circo Coruñés», en 1905 el empresario Lino Pérez decidió levantar detrás del actual «Kiosco Alfonso» un edificio multifuncional —donde se mostraron películas y espectáculos varios como bailarinas, fantoches, obras de género chico, prestidigitadores, autómatas, etc. - y que se conoció por el nombre de «Pabellón Lino» o «Cinematógrafo Coruñés» hasta 1919 —aunque bajo diferentes construcciones—, año en el que pereció en un incendio.

Así que desde el verano de 1905 los coruñeses disfrutaron de un nuevo local provisional para la diversión (fig. 12) de 10×30 m, realizado en madera y fábrica, en estilo modernista, con cubierta a dos aguas, disposición lateral y distribuido internamente en vestíbulo, patio de butacas, graderío y escenario con orquesta, destacando el acceso y las puertas de salida en el lateral orientado a los jardines de Méndez Núñez.

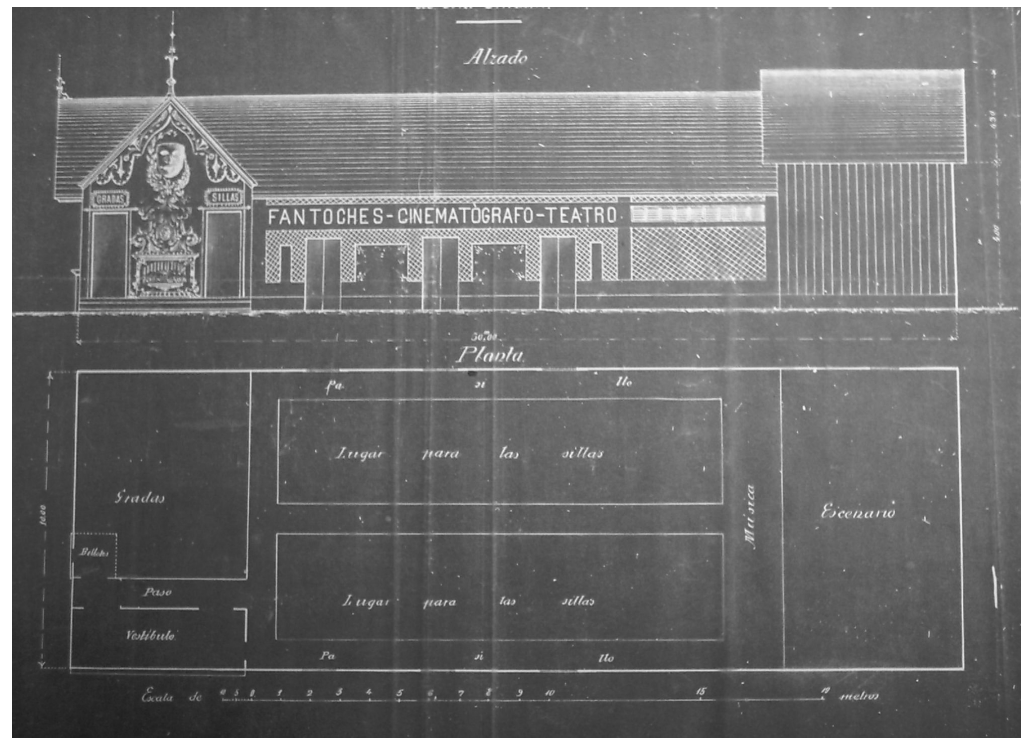

Fig. 12. Teatro de Lino Pérez: fachada y planta, 1905.

Pero antes de un año este local se derribó porque se hacía pequeño e inadecuado dado que no poseía la suficiente solidez y arte para espectáculos que crecían en calidad, así que se sustituyó por el segundo «Pabellón Lino»30, también

30 En la carta que Lino Pérez remitió al alcalde el 27 de abril de 1906 solicitaba «un pabellón dedicado a espectáculos públicos, del que tiene el honor de acompañar el plano correspondiente y el que compren-

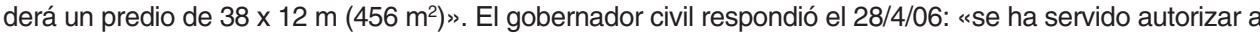
don Julio Pradera y a don Lino Pérez los derechos para instalar un pabellón cinematográfico, el primero, y para dar espectáculos públicos el segundo, en terrenos de la zona del puerto comprendido entre la caseta de carabineros y la de salvamento de náufragos [en la zona de los muelles que da frente al Relleno] im- 
de vocación efímera, interior diferenciado, formas regulares, bien pintado, decorado convenientemente en estilo modernista, con mejores condiciones de seguridad y mayor capacidad y tamaño, pues medía 38x12 m (456 m²).

Y por lo que se escribió en la prensa del momento debió ser así: «(tiene) capacidad para 600 personas, distribuidas en 17 filas de butacas, en 2 de anfiteatro y en una amplia gradería para el público de entrada general. Cuenta con un magnífico salón de espera, cómodo e higiénico y decorado con encantadora sencillez. Predominan en todo el edificio, espléndidamente iluminado con luz eléctrica, los tonos claros. (Destaca también) el hermoso expresivo que figura al frente de la portada, iluminada con 200 lámparas eléctricas de diversos colores, que dan a la entrada, modernista, y de un orden arquitectónico en consonancia con el órgano, un aspecto fantástico »31. Además estaba bien ventilado y las ligeras estructuras de madera y cristal así como su alegre, colorido e imaginativo diseño resultaron muy atractivos al público.

Por las fotografías halladas (figs. 13 y 14) se deduce que la disposición de la entrada era la misma que en 1905, es decir, lateral, con un vestíbulo y dos puertas laterales por las que se accedía a las gradas y a la platea; pero se diferenciaba en la colocación de la billetería —antes en otro lateral y ahora en el vestíbulo-, en las tres columnas estructurales de la fachada —que desde 1913 serían cuatro-, en las cartelas y en la decoración, que aunque seguía manteniendo el aspecto festivo, tenía forma ovalada y variaba de estilo, posiblemente cada temporada.

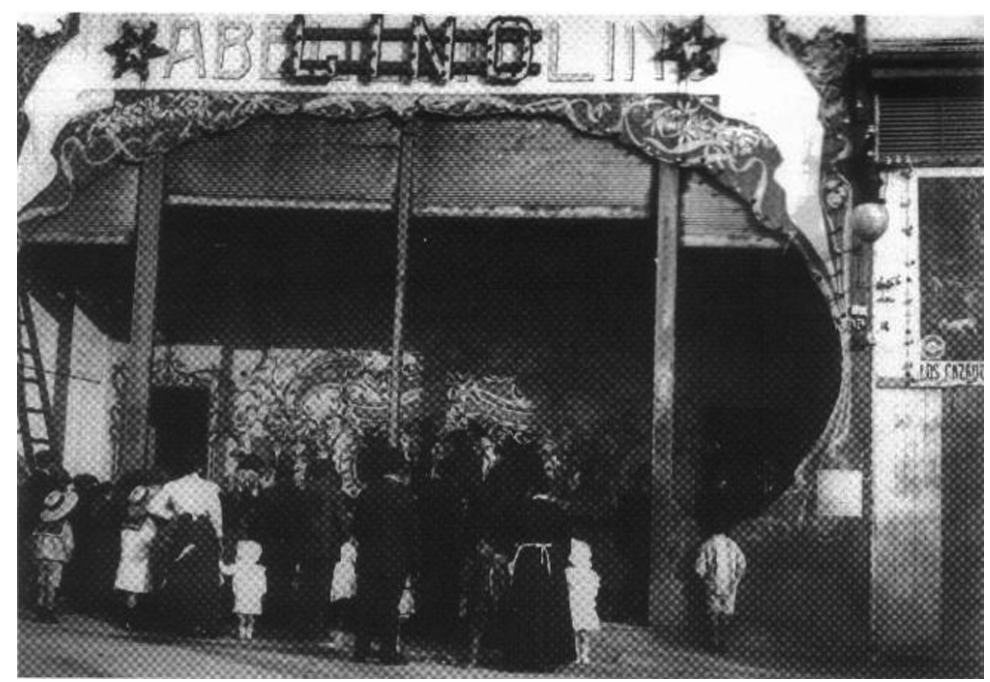

poniendo, entre otros, las siguientes condiciones: ambos pabellones serán de formas regulares y reunirán las condiciones de seguridad por las que corresponden al objeto para que se destinan y al punto en que han de ser emplazados, estando pintados y decorados convenientemente». AMC, Vía pública, caja 2156.

31 En publicación El Noroeste 28/6/1906 según VIGO TRASANCOS, A. (coord.), Fontes e documentos para a historia da arquitectura e do urbanismo en Galicia, vol. II, La Coruña, Xunta de Galicia, 
Fig. 13. Teatro de Lino Pérez: fachada, sin fecha.

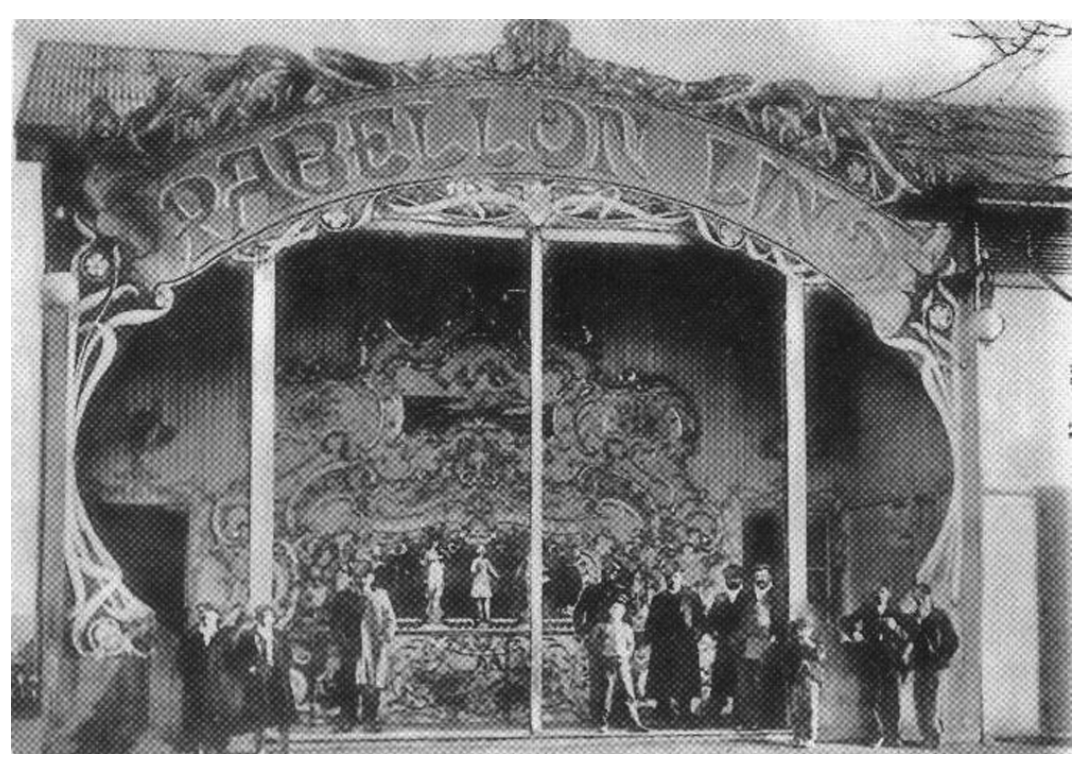

Fig. 14. Teatro de Lino Pérez: fachada, 1908 ca.

Se puede afirmar entonces que en 1906 Lino Pérez controlaba la mayor parte de los espectáculos coruñeses pues gestionaba el «Teatro Principal», el «Teatro-circo E. Pardo Bazán», además de este local, que era el mejor establecimiento teatral efímero instalado en la zona de Méndez Núñez.

Posteriormente el «Pabellón Lino» sufrió varias reformas para lograr mayor arte, solidez e higiene, así que en 1909 se mejoraron los aseos y en 1913 el arquitecto Antonio López Hernández realizó un nuevo proyecto (figs. 15 y 16) basado en el multifuncional quiosco-cinematógrafo de T. Civeira que proyectara P. Mariño en $1912^{32}$. El «Pabellón Lino» de 1913 fue el que más se recuerda por ser el último y más reproducido en las fotografías, sobre todo los dos grandes mascarones modernistas del acceso realizados en yeso que representaban la tragedia y la comedia clásica, y es que el Modernismo era un estilo muy decorativo, vistoso, alegre y festivo, y en consecuencia, acorde a la tipología del edificio, hasta el punto de influir en otros edificios lúdicos posteriores como el teatro Linares Rivas de $1919^{33}$.

2000, pp. 1232-3; FERNÁNDEZ FERNÁNDEZ, X., Arquitectura del Eclecticismo en Galicia (1875-1914), vol. II, Universidad de A Coruña, A Coruña, 1996, p. 255 y CASTRO DE PAZ, J. L., La Coruña y el cine I: 100 años de historia 1896-1936, A Coruña, Vía Láctea, 1995, p. 43.

32 AMC, Vía pública, caja 2157.

33 FERNÁNDEZ FERNÁNDEZ, X., Op. cit., p. 392. 
Construcciones teatrales provisionales en La Coruña de 1900. Otra tipología...

En este proyecto de 1913 se aprecia una construcción modular y similar a la de 1905, es decir, longitudinal, con cubierta a dos aguas, con fachada principal en el paseo de Méndez Núñez y tripartita — diferenciándose a la izquierda el acceso muy decorado también en estilo modernista, una zona intermedia para el público formada por siete módulos iguales en la que había tres vanos y a la derecha, un cuerpo más alto de tres módulos donde se situaba el escenario y su maquinaria-; mientras que en el lado menor - formado por cinco módulos - se dispone en el centro la puerta del escenario y elementos decorativos como cornisas, rótulos y banderolas.
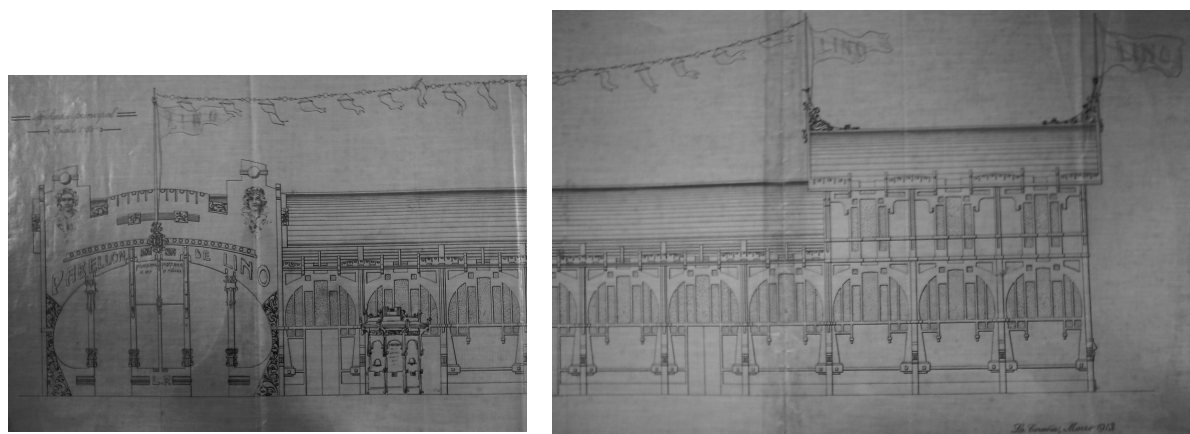

Fig. 15. Teatro de Lino Pérez: fachada (detalles), 1913.

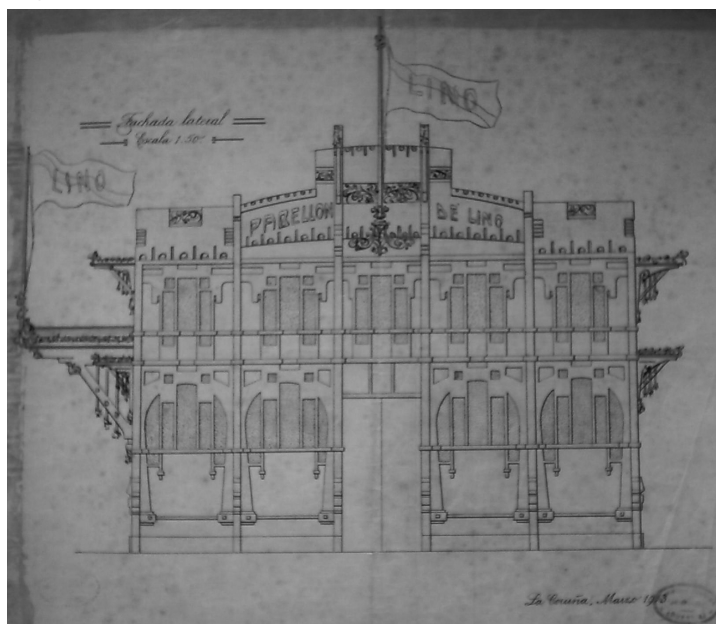

Fig. 16. Teatro de Lino Pérez: alzado lateral, 1913.

En el período de 1914-6 de nuevo se hicieron mejoras ${ }^{34}$ en los aseos —basándose posiblemente en el proyecto de 1909-, en el revestimiento exterior y otros elementos, quedando el exterior tal y como se aprecia en las fotografías de la época (figs. 17 y 18).

${ }^{34}$ En vista de las mejoras decorativas que se realizaban — por imperativo legal - en los quioscos del paseo de Méndez Núñez en 1914, el propietario decidió mejorar los aseos y «a tal fin se ampliaría la su- 
En 1918 falleció Lino Pérez y al año siguiente — siendo ya el propietario Isaac Fraga - el «Pabellón Lino» desapareció víctima de un incendio, así que el nuevo dueño encargó un nuevo proyecto al arquitecto Eduardo Rodríguez Losada que no llegó a construirse porque el señor Fraga decidió invertir en otros espectáculos como el arriendo del Teatro Rosalía ${ }^{35}$.

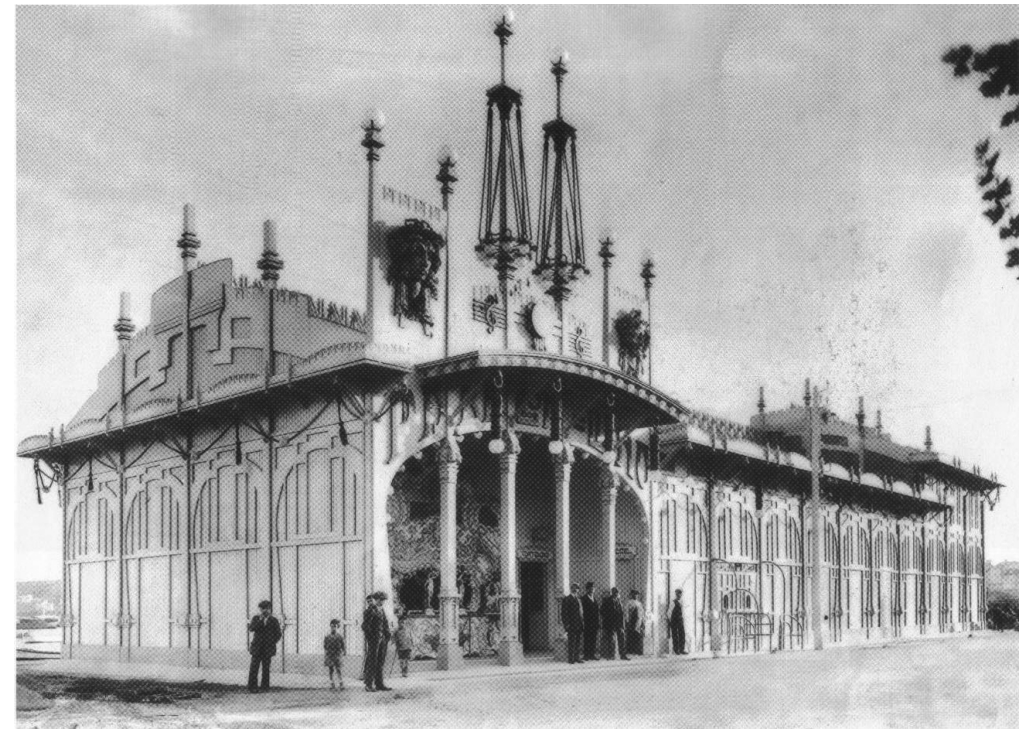

Fig. 17. Teatro de Lino Pérez: vista general, s/f.

perficie destinada a retretes y se les dará luz directa por dos grandes montantes de $2 \mathrm{~m}$ de longitud cada uno construido en persiana de vidrio protegidos con rejas de hierro, siendo todos los tabiques después de los $2 \mathrm{~m}$ de altura también de persianas de vidrio imprimé para que la luz llegue a todos los puntos y la ventilación quede asegurada de un modo eficaz con la circulación de una corriente continua del aire del exterior que saldrá por encima del tejado mediante un sistema de grandes tubos ventiladores». También solicitó «pintado general y reposición del cerramiento metálico, que se halla en mal estado sin modificar la estructura de la construcción en nada ni ampliar su superficie», y en la memoria se indicaba que el revestimiento exterior consistía en colocar en sus frentes «arcadas de tabla recortada y pintada para simular ventanales cuyo vidrio se colocará sobre los entrepaños de madera existentes. También se sustituirán por otros nuevos los actuales cierres metálicos que se hallan en mal estado. En el croquis adjunto [inexistente] se da idea de las modestas obras que se han de ejecutar, debiendo significar que los vuelos de marquesinas se reducirán notablemente hasta no rebasar de 0'40 m por no permitirlo la distancia a que se hallan los hilos telegráficos». También se hacía referencia a una chimenea «que saldrá por encima del tejado mediante un sistema de grandes tubos ventiladores; los tabiques hasta la altura de $2 \mathrm{~m}$ serán de masilla revestidos de azulejos; las puertas y techos se pintarán de esmalte blanco; el suelo será de baldosín sobre hormigón; los retretes, urinarios y lavabos serán de porcelana y dotados de agua con presión; las tuberías de acometidas serán de gres, de los diámetros apropiados y en las pendientes reglamentarias, ventilándose el sistema con 1 tubo que peraltará sobre la cubierta y ejecutándose todo con arreglo a las vigentes ordenanzas de construcción, a la de saneamiento y a las disposiciones de la alcaldía».

En 1916 el Ayuntamiento decidió que los locales públicos debían tener servicios por lo que a finales de ese año se concedió a Lino Pérez permiso para construir cuatro retretes y cuatro urinarios para servicio del público que asistía a los espectáculos del pabellón, emplazándolos independientes en el local destinado a salón de espera y adosándolos al frente sur que da a la zona del puerto, por donde tendrían luz y ventilación directas, con arreglo a las ordenanzas. AMC, Vía pública, caja 2156.

35 FERNÁNDEZ FERNÁNDEZ, X., Op. cit., p. 257 y CASTRO DE PAZ, J. L., La Coruña y el cine I..., p. 72. 


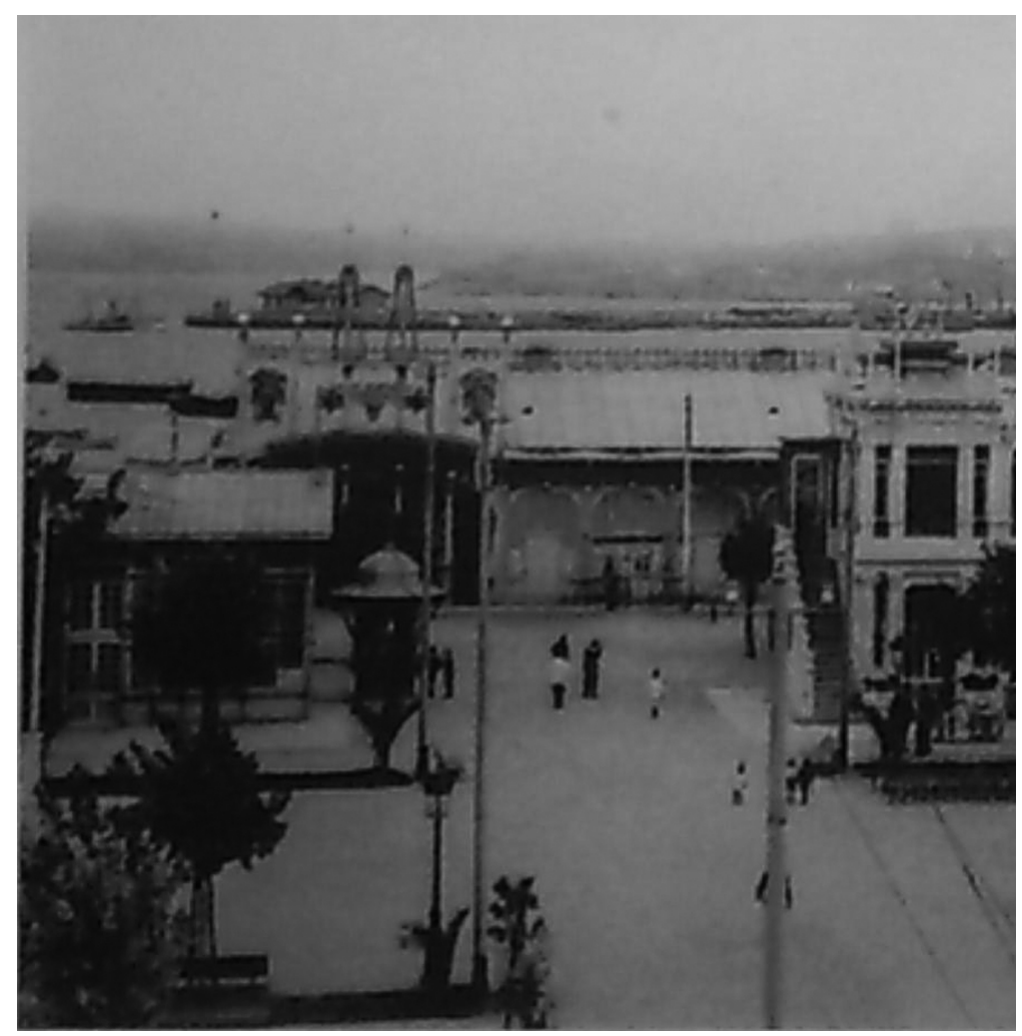

Fig. 18. Teatro de Lino Pérez: ubicación, 1910-19.

Durante el verano de 1921 Lino Rodríguez estableció «en terrenos de la zona de puerto de esta capital, frente al quiosco «La terraza» por la parte de atrás, (...) un pabellón de madera portátil, (...) para dedicarlo a la exhibición de varietés, cuyas dimensiones son $15 \times 5 m$ conforme al diseño que se acompaña», muy similar en función y forma —aunque de dimensiones menores - al que levantó Lino Pérez en 1906, es decir, era un teatro (figs. 19 y 20) sencillo, con cubierta a dos aguas, longitudinal, con varios vanos en su frente y acceso diferenciado, decorado y lateral $^{36}$.

${ }^{36}$ AMC, Vía pública, caja 2587. 


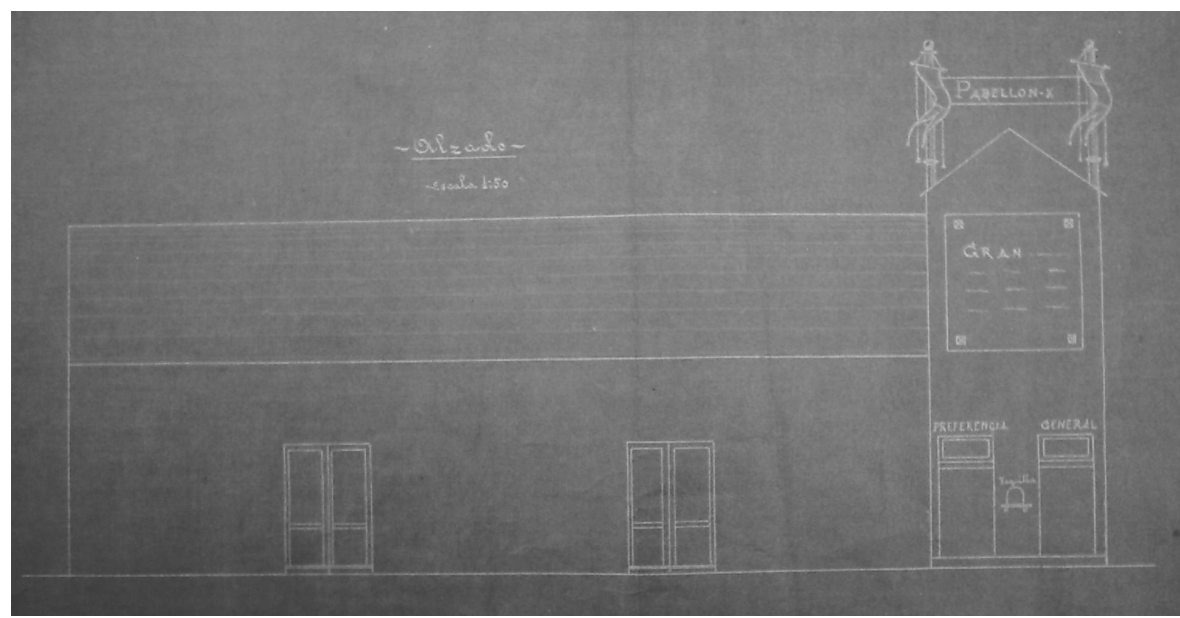

Fig. 19. Teatro de L. Rodríguez: fachada, 1921.

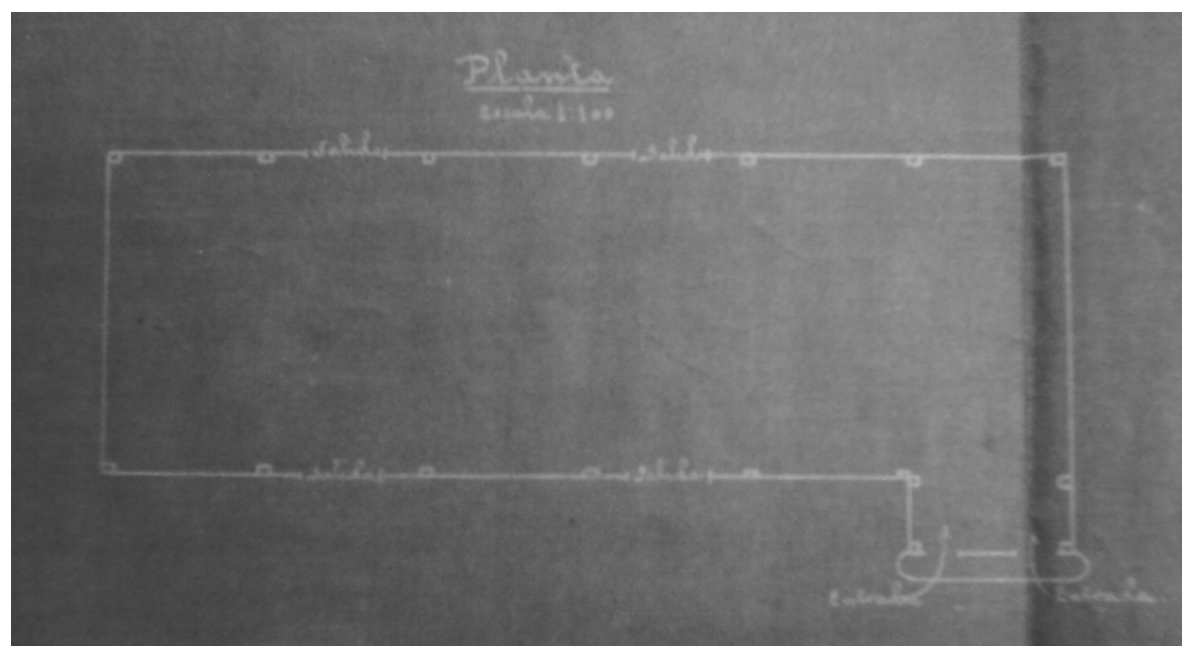

Fig. 20. Teatro de L. Rodríguez: planta, 1921.

Como en el segundo cuarto del siglo XX ya proliferaban los recintos teatrales permanentes, cada vez había menos solicitudes para instalar barracones teatrales y la farándula itinerante — que hasta entonces hacía allí sus representacionespasó a actuar en los salones de variedades.

Aún así en 1925 José Iglesias Osorio construyó en la zona de Obras del Puerto y durante la temporada de festejos, una caseta denominada «Gran Guiñol» de $50 \mathrm{~m}^{237}$.

37 AMC, Vía pública, caja 2158. 
En 1929 Guillermo Pupino de la Llave instaló una barraca de varietés de $40 \mathrm{~m}^{2}$ durante las fiestas de verano en la zona del puerto, donde se instalaban las demás barracas ${ }^{38}$.

Y en 1931 José Harce instaló —como en años anteriores-y en los terrenos de Correos, una caseta de espectáculos denominado «Teatro Iris», de 12x6 m; Fernando Vela Alegre parece que instaló un espectáculo de gran novedad durante las fiestas de María Pita en la zona de Correos, de 6x12 m; posiblemente Marcelino Bericat y Abadía instaló —entre otras - una caseta de bailes regionales de $5 \times 10 \mathrm{~m}$; y José Oliver posiblemente colocó —entre otras - una caseta para espectáculos de 10x8 $\mathrm{m}$ denominada «Novios amaestrados» ${ }^{39}$, siendo éstas las últimas construcciones de carácter teatral no permanentes que se instalaron en A Coruña durante el primer tercio del siglo $\mathrm{XX}$, ya en la zona de Obras del Puerto o Correos y con una superficie media de $50 \mathrm{~m}^{2}$.

Para concluir se puede afirmar que estas arquitecturas promovidas por los empresarios ambulantes se levantaron anualmente —coincidiendo con la celebración de la victoria de $\mathrm{M}^{\mathrm{a}} \mathrm{P}$ Pita sobre Drake- durante los meses de verano, característica esta última que las diferencia de las arquitecturas conmemorativas que se erigían en su mayoría independientemente del calendario local.

Fueron aproximadamente veinte construcciones teatrales o parateatrales de promoción privada que amenizaron —a veces contemporáneamente y junto a otras arquitecturas lúdicas permanentes o no- las jornadas coruñesas durante varios decenios, primero en la zona de Puerta Real, de 1880 a 1925 en el paseo de Méndez Núñez y a partir de entonces en la zona de la Junta de Obras del Puerto o Correos.

Eran arquitecturas de estilo clásico y modernista generalmente; en su mayoría de planta rectangular; realizadas en hierro y madera pintada; con unas dimensiones que variaban —dependiendo de la época, de la solvencia del promotor o de la temporalidad de la obra- de los 30 a los $200 \mathrm{~m}^{2}$, siendo la media de $100 \mathrm{~m}^{2}$; y de las cuales se desconoce el autor y el coste por ser arquitecturas de promoción privada.

Al analizar la información anteriormente expuesta y compararla con otros estudios $^{40}$ lo primero que hay que indicar es que los datos hallados sobre las diferentes tipologías de construcciones efímeras lúdicas coruñesas son muy heterogéneos tanto en cantidad como en calidad, siendo bastante abundantes en el caso de los teatros o cines pero muy escuetos en el caso de carruseles.

\footnotetext{
38 AMC, Vía pública, caja 2159.

39 Ibídem.

40 VILLASUSO FERNÁNDEZ, L. M., Arquitectura efímera..., pp. 158-164 y 196-241.
} 
Aún así se deduce que las tipologías más frecuentes dentro de la arquitectura lúdica fueron los tiovivos, carruseles, columpios o voladoras, las estructuras para la práctica de tiro, seguidas de circos, teatros y cines, siendo las menos frecuentes las plaza de toros, de lo que se deduce que la cantidad era directamente proporcional a la eventualidad de la construcción e inversamente proporcional a su tamaño y a los requisitos de seguridad exigidos para levantarlas.

Con respecto a las etapas más prolíficas, teatros, plazas de toros y otras arquitecturas lúdicas empezaron a proliferar desde mediados del siglo XIX como consecuencia del auge de la burguesía que deseaba espacios para el esparcimiento y lucimiento. Las arquitecturas ambulantes teatrales en concreto se propagaron desde finales del siglo XIX hasta finales del primer tercio del siglo XX, momento en que fueron desapareciendo para instalarse en recintos más estables o para dejar sitio a espectáculos más novedosos como el cine y el tiro al blanco o de pelota.

Aunque el Municipio financió la mayor parte de las arquitecturas efímeras conmemorativas no sucedió lo mismo con las arquitecturas de carácter lúdico, así que la mayor parte de los recintos lúdicos fueron promovidos por empresarios coruñeses aunque también los hubo venidos de Madrid, Barcelona e incluso del extranjero. Algunos de estos empresarios llegaron a ser muy conocidos en la ciudad por por gestionar indistintamente espectáculos teatrales o cinematográficos como Lino Pérez.

En relación a los autores de las arquitecturas coruñesas de carácter lúdico se conocen los nombres de los arquitectos municipales —como Faustino Domínguez o Juan de Ciórraga- que participaron en el diseño de algún teatro-circo pues estas construcciones para el gran público debían cumplir una estricta normativa en cuanto a estabilidad y seguridad, y era imprescindible presentar el proyecto para obtener el permiso pertinente para su construcción. Pero del resto de obras se desconoce el autor porque posiblemente fueron realizadas por el mismo dueño o por algún carpintero designado por el mismo, dado que hasta el siglo XX no era necesario presentar el proyecto pues estas arquitecturas se consideraban obras ornamentales o accidentales.

En cuanto a los estilos de las arquitecturas efímeras lúdicas, éstos coincidían básicamente con los de la arquitectura conmemorativa y comercial, lo que permite deducir que el estilo elegido era consustancial a una época y no a una tipología concreta como apuntó algún autor con respecto a las arquitecturas efímeras lúdicas coruñesas.

No se encontraron documentos escritos que indicasen explícitamente el estilo de las plazas de toros, circos, cines o arquitecturas para tiro levantadas en A Coruña, aunque de los gráficos se desprende que el estilo en ocasiones era indeter- 
minado porque -independientemente de la falta de recursos, tiempo o imaginación del promotor- estas construcciones temporales respondían más a la función que al estilo.

En líneas generales e independientemente de los proyectos de arquitecturas teatrales de estilo hispanomusulmán no llevados a cabo, los teatros provisionales coruñeses de finales del siglo XIX fueron de estilo clásico imitando los templos griegos - con columnas, entablamentos, frontones decorados y cubierta a dos aguas - posiblemente para dignificar la construcción y el espectáculo y en consecuencia obtener con mayor facilidad la licencia, de lo contrario se hubiesen realizado —dado que se levantaban principalmente en la época estival, cuando condiciones meteorológicas no eran adversas- con cubiertas planas, más económicas y menos complejas. Sin embargo la escenografía y la decoración interior, aquello que escapaba a la concesión del permiso de construcción, era menos sobria y en ella primaba la ornamentación atrevida, fantástica, preciosista, de ensueño u oriental, también denominada de evasión y contraria al academicismo de años anteriores, de modo que la escenografía que disfrutaron los coruñeses hasta 1903 fue de estilo hispanomusulmán y desde entonces de estilo modernista, es decir, el contenido era menos comedido que el continente.

Por su parte las construcciones efímeras lúdicas en general se levantaron en estilo clásico e hispanomusulmán durante el último tercio del siglo XIX y en estilo modernista desde principios del siglo XX.

Eran todas ellas arquitecturas de gran economía material e incluso estructural, con paramentos laterales y posteriores exteriores casi completamente lisos pero con fachadas destacadas - siguiendo el ejemplo de los templos romanos-con cintas, banderas, símbolos, yeserías y otros elementos que evocaban el mundo de lo maravilloso y festivo.

Basándose en la planta, las arquitecturas efímeras lúdicas coruñesas se dividían en dos tipos, aquellas que tenían forma circular o poligonal centralizada hexagonal, octogonal, etc.- , como las plazas toros, circos, carruseles o estructuras para tiro al blanco y aquellas que tenían planta cuadrangular o rectangular como los teatros, cines y estructuras para exhibiciones.

Con respecto al tamaño, las dimensiones variaban dependiendo de la tipología, época y promotor, pero en general el tamaño - junto con la calidad, solidez y seguridad- de estas arquitecturas fue aumentando a medida que transcurrieron los años, pasando por ejemplo de los $2 \mathrm{~m}^{2}$ de un cinematógrafo en 1902 a los $2210 \mathrm{~m}^{2}$ de un circo en 1923; de todos modos en general se podría afirmar que fueron más grandes que las arquitecturas conmemorativas y comerciales. De manera detallada se aprecia que los teatros tenían planta rectangular y un interior dividido generalmente en vestíbulo, patio de butacas, escenario y zona de maquinaria, con una superficie media de $100 \mathrm{~m}^{2}$ que variaba en función de la época, de la solven- 
cia y exigencia del promotor pero sobre todo de la temporalidad de la obra. $Y$ el hecho de que, por ejemplo, el teatro de A. Tudela en 1886 fuese siete veces más grande que el de L. Pérez en 1903 indica que a finales del siglo XIX había una gran demanda de espectáculos teatrales por parte de la sociedad coruñesa hasta que se popularizó el cine y aquellos empezaron a ser espacios multifuncionales en los que se desarrollaban contemporáneamente o no actividades teatrales, circenses o cinematográficas.

Sobre los materiales empleados en las arquitecturas coruñesas de carácter lúdico se puede afirmar que la gran mayoría de estas arquitecturas se realizaron en madera - como casi todas las arquitecturas conmemorativas y comerciales- posiblemente por ser un material económico, de fácil adquisición, manejo, uso y reutilización. En realidad, sólo algunos carruseles y tiovivos del siglo XX se realizaron en metal pues antes de 1900 incluso éstos eran de madera; el resto de tipologías como plazas de toros, teatros, circos - recubiertos de lona-, cines y estructuras para tiro y para exhibiciones tenían estructura de madera, a veces reforzada con hierro y piedra y adornada con otros materiales como vidrio o cerámica.

Con respecto a los colores de estas arquitecturas, los escasos documentos gráficos hallados - fotografías o bocetos coloreados- sólo permiten afirmar que los teatros provisionales estarían pintados en tonos llamativos y fuertes como rosas o verdes, con fachadas ornadas con elementos de colores alegres y patrióticos como el rojo y amarillo, sin olvidar que los bocetos podían diferir de la construcción final.

Por otra parte y dado que la mayor parte de los promotores de las arquitecturas lúdicas eran privados, no hay constancia -al menos en los archivos públicos consultados- de los costes en que incurrieron los mismos para construirlas, pero el hecho de que hubiese que pagar impuestos al Ayuntamiento por ocupación de vía pública, permitió deducir no sólo la superficie ocupada sino también la permanencia de las instalaciones lúdicas, que resultó ser superior a la permanencia de las arquitecturas conmemorativas ya que permanecían varias semanas en la ciudad - aunque menos de un mes-, el tiempo que duraba la fiesta local.

En relación a la ubicación, las arquitecturas eventuales de carácter lúdico se situaron generalmente en los jardines Méndez Núñez y en la zona de la Junta de Obras del Puerto o de Correos, es decir, en los mismos sitios aproximadamente en los que se dispusieran las arquitecturas conmemorativas y comerciales, exceptuando la Ciudad Vieja.

Con respecto a la calidad de estas arquitecturas, ésta dependía del promotor porque existieron construcciones de calidades muy diferentes en la misma época, 
pero en general la mayor evolución la sufrieron los teatros y cines dado que pasaron de ser simples barracones de madera a tener interiores diferenciados y fachadas muy elaboradas. También hay que destacar la diferencia de calidad entre proyectos, siendo los más elaborados y completos —evidentemente- los realizados por el arquitecto municipal, mientras que el resto y la gran mayoría eran bocetos simples y mal dibujados, pero de gran interés documental y que se encontraban todavía sin publicar.

Aunque lo más importante de las arquitecturas efímeras lúdicas -al contrario que las arquitecturas conmemorativas - es que sí fueron precedentes de las arquitecturas permanentes lúdicas de misma tipología como plazas de toros, teatros o cines no eventuales.

\section{ELENCO DE ILUSTRACIONES}

Fig. 1. Teatro de A. Aller: fachada, 1880. AMC, Vía pública, C-2153.

Fig. 2. Teatro de A. Aller: alzado lateral, 1880. Ibídem.

Fig. 3. Teatro de B. Sánchez: fachada y planta, 1884. Ibídem.

Fig. 4. Teatro de S. Delgado, 1885. AMC, Vía pública, C-2154.

Fig. 5. Teatro de A. Tudela, 1886. Ibídem.

Fig. 6. Teatro de J. Mํㅡㄹ Rodríguez: planta, 1890. Ibídem.

Fig. 7. Teatro de J. Mํㅡㄹ Rodríguez: fachada, 1890. Ibídem.

Fig. 8. Teatro de J. Mª Rodríguez: sección, 1890. Ibídem.

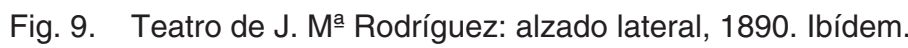

Fig. 10. Teatro de E. Rabadán: fachada y sección, 1902. AMC, Vía pública, C-2155.

Fig. 11. Teatro de E. Rabadán: alzado lateral, 1902. Ibídem.

Fig. 12. Teatro de Lino Pérez: fachada y planta, 1905. AMC, Vía pública, C-2156.

Fig. 13. Teatro de Lino Pérez: fachada, sin fecha. Archivo personal de J. R. Soraluce.

Fig. 14. Teatro de Lino Pérez: fachada, 1908 ca. AMC, Colección de postales, signatura 2278.

Fig. 15. Teatro de Lino Pérez: fachada (detalles), 1913. AMC, Vía pública, C-2587.

Fig. 16. Teatro de Lino Pérez: alzado lateral, 1913. Ibídem.

Fig. 17. Teatro de Lino Pérez: vista general, sin fecha. Archivo personal de J. R. Soraluce.

Fig. 18. Teatro de Lino Pérez: ubicación, 1910-19. AMC, Colección de postales, signatura 317.

Fig. 19. Teatro de L. Rodríguez: fachada, 1921. AMC, Vía pública, C-2587.

Fig. 20. Teatro de L. Rodríguez: planta, 1921. Ibídem. 


\section{FUENTES}

\section{Manuscritos del archivo municipal de A Coruña}

Libros de actas: caja 130.

Sección de teatro: caja (1768-1809).

Vía pública: cajas 2153, 2154, 2155, 2156, 2157, 2158, 2159 y 2587.

\section{Bibliografía}

Agrasar, F. (ed.), A Coruña: arquitectura desaparecida, A Coruña, COAG, 2004.

Barreiro Fernández, X. R., Historia de la ciudad de La Coruña, La Coruña, La Voz de Galicia, 1986.

CAstro de Paz, J. L., La Coruña y el cine l: 100 años de historia 1896-1936, A Coruña, Vía Láctea, 1995.

Castro de Paz, J. L. y Folgar de la Calle, J. Mà., José Sellier; La Coruña y los orígenes del cine en España, A Coruña, Vía Láctea, 1996.

Fernández Fernández, X., Arquitectura del Eclecticismo en Galicia (1875-1914), vol. II, Universidad de A Coruña, A Coruña, 1996.

GonzÁlez Catoyra, Temas coruñeses, La Coruña, Ayuntamiento de La Coruña, 1991.

Martínez-Barbeito, I., «Una reina en La Coruña» en diario La Voz de Galicia, 1/9/1965.

Pérez Costantı, P., Notas Viejas Galicianas, t. II, Vigo, Sindicatos Católicos, 1925.

SÁnchez García, J. A., La Arquitectura teatral en Galicia, A Coruña, Fundación Pedro Barrié de la Maza, 1997.

SoraluCE BLOND, J. R., «El espacio del espectáculo: Los primeros teatros de Galicia» en Boletín Académico da Escola Técnica Superior de Arquitectura da Coruña, № 9, La Coruña, Universidade da Coruña, 1988.

Tettamancy Gastón, F., Apuntes para la Historia Comercial de La Coruña, La Coruña, Excmo. Ayuntamiento de La Coruña, 1994.

Vedia y Goossens, E., Historia y descripción de La Coruña, La Coruña, 1845.

Villasuso Fernández, L. M., Arquitectura efímera de carácter conmemorativo, lúdico y comercial levantada durante la época contemporánea en la ciudad de A Coruña (Tesis doctoral s. p.), UNED, 2010.

Villasuso Fernández, L. M., «Arcos de triunfo efímeros erigidos en la ciudad de A Coruña para los monarcas que la visitaron en la segunda mitad del siglo XIX» en revista Espacio, Tiempo y Forma, Madrid, UNED, 2008.

Vigo Trasancos, A. (coord.), Fontes e documentos para a historia da arquitectura e do urbanismo en Galicia, vol. II, La Coruña, Xunta de Galicia, 2000.

Vigo Trasancos, A., La arquitectura de la Ilustración, La Coruña, Vía Láctea, 1995.

VV. AA., Historia del teatro, San Sebastián, Uteha, 1980. 